\title{
Introduction to OSCE Insights 2020: The OSCE in Crisis Mode
}

\author{
Cornelius Friesendorf
}

To cite this publication: Cornelius Friesendorf, Introduction to OSCE Insights 2020: The OSCE in Crisis Mode (Baden-Baden: Nomos, 2020), https://doi.org/10.5771/9783748922339-00

This is the first volume of OSCE Insights, the new publication series of the Centre for OSCE Research (CORE), Institute for Peace Research and Security Policy at the University of Hamburg (IFSH). As the successor to the OSCE Yearbook, published by the IFSH from 1995 to 2019, OSCE Insights focuses on OSCE-relevant topics in all three dimensions, including conflict management, human rights, security sector governance and reform, arms control and military confidence-and security-building measures (CSBMs), environmental protection, and economic connectivity. We also analyse changes to the OSCE's structure and participating States' interests in, and policies towards, the organization.

OSCE Insights presents policy papers written by scholars and policy analysts and by OSCE and government officials. By making research findings more accessible to decision-makers and practitioners, and by offering actionable recommendations, the series contributes to the

* Dr habil. Cornelius Friesendorf Institute for Peace Research and Security Policy at the University of Hamburg (IFSH) friesendorf@ifsh.de
OSCE's aim of promoting comprehensive, cooperative, equal, and indivisible security.

All papers are published in English, Russian, and German. They are made available online throughout the year in an open-access format in the e-library of our publisher, Nomos, and on the IFSH website. In addition, all contributions are published in an annual print edition also in English, Russian, and German - at the beginning of each year. Double-blind peer review and stringent editing ensure that the reader receives reliable up-to-date information presented in non-bureaucratic language.

This first volume of OSCE Insights focuses on crises. Its subtitle - "Corona, War, Leadership Crisis" - highlights three crises that impacted the OSCE in 2020. First, the global coronavirus pandemic affected the day-to-day operations of the OSCE and forced it to conduct its activities online. The lack of face-to-face interaction has been detrimental to the OSCE, which relies heavily on diplomacy conducted in person, often in informal settings. Second, the conflict between Armenia and Azerbaijan once again escalated to full-blown war, fundamental- 
ly changing the distribution of power around the disputed territory of Nagorno Karabakh. Meanwhile, the war in Eastern Ukraine continued to kill and maim. Third, in perhaps the most dramatic institutional crisis in OSCE history, the four leadership positions of the Secretariat, the Office for Democratic Institutions and Human Rights, the High Commissioner on National Minorities, and the Representative on Freedom of the Media were vacant for months after several participating States chose not to endorse the extension of the incumbents' mandates due to parochialism, misgivings about being criticized by OSCE institutions, and miscalculation.

The contributions to the 2020 edition of OSCE Insights analyse different types of crises. A first group of papers examine the difficulties of translating OSCE commitments into action and failures to make systematic use of existing OSCE instruments.

In the first contribution, I look at the challenges of providing OSCE support to democratic policing in Central Asia. Governments are keen to receive technical law enforcement aid and invite or tolerate efforts to improve local initiatives to enhance human security, but critical police oversight (such as oversight by civil society) meets continued resistance from Central Asian governments (and from Russia) as liberal models of security sector governance and reform threaten patronal logics. The adaptation of OSCE field operations to host state priorities is in line with the OSCE principle of national ownership but risks reinforcing authoritarianism.
Andrew Baker discusses another area in which the implementation of OSCE commitments has been problematic: the fight against antisemitism. Baker documents the uneven protection that governments in the OSCE area afford to Jewish communities, even though these communities face high risks. Baker points to the OSCE's mixed record with regard to adopting and implementing a comprehensive definition of antisemitism and shows how the consensus principle and personnel changes at the OSCE have compromised the organization's ability to take swift and decisive action against it.

Michael Raith demonstrates that the OSCE has a broad range of conflict management tools that are vital both to preventing and resolving violent conflict and to supporting states and societies once the fighting has ended. However, the OSCE has had difficulty making full use of these tools, not least because of funding shortages and a lack of interest on the part of participating States. Raith's findings suggest that even small additional investments, such as increasing staff in the Situation/Communications Room of the Conflict Prevention Centre, could make a difference in crucial areas, such as early warning.

Sebastian Mayer's analysis of Kazakhstan's ambitions to host an OSCE centre on connectivity reveals the extent to which states are increasingly contesting OSCE commitments, particularly in the third, human dimension. The à la carte approach favoured by Kazakhstan raises questions about the future of the human dimension, and thus about the concept 
of comprehensive security and, by extension, the OSCE as a whole. Kazakhstan's demands indicate power shifts within the OSCE area - with many participating States no longer accepting the role of norm-taker - and the failure of teleological models of democratization.

Contributions 5, 6, and 9 also identify challenges to OSCE commitments and participating States that are not fully exploiting the potential of the OSCE. Alexander Lambert, Filip Ejdus, and Thomas Schmidt examine domestic deployments of military forces in the OSCE area in efforts to cope with the coronavirus pandemic. They use the 1994 OSCE Code of Conduct on Politico-Military Aspects of Security as a benchmark for judging the appropriateness of internal military roles during the crisis. While states have generally complied with the Code, the authors also showcase problems, including military activities that raise questions about necessity, proportionality, and non-discrimination.

The war between Armenia and Azerbaijan over Nagorno Karabakh in autumn 2020, analysed by Philip Remler, Richard Giragosian, Marina Lorenzini, and Sergej Rastoltsev, constituted a violation of a central OSCE principle: the non-use of force in settling disputes. The authors also show that before and during the war, the OSCE Minsk Group, as the main international negotiation format for reaching a peaceful resolution to the Karabakh conflict, was sidelined.

Frank Evers, André Härtel, and Marietta König discuss cooperation between the OSCE and the Council of Europe. Their overlapping and complementary functions and the fact that they are both affected by the crisis of multilateralism make these two organizations natural partners. However, senior-level meetings take place infrequently and in a ritualized way, and the field presences of the two organizations do not cooperate with one another systematically.

Another group of papers in OSCE Insights 2020 reveals the starkly opposed positions of participating States that have stymied efforts to build trust and settle conflicts peacefully. Philip Remler and his co-authors argue that the Co-Chairs of the Minsk Group were unable to engage effectively in negotiating peace because of the intransigent and incompatible positions held by Armenia and Azerbaijan, the leaders of which had voiced maximalist demands for so long that their domestic constituents were not ready to accept compromises.

Benjamin Schaller shows that, at the working level, arms control units from different states continue to implement CSBMs effectively. Nevertheless, these positive transnational relations are insufficient for building trust between Russia and Western states at the political level.

Focusing on societal narratives on the war in Eastern Ukraine, Cécile Druey, Anna Hess, Julia Kaplan, and Valentina Cherevatenko present empirical research findings that will be sobering to those who assume that, while political leaders may seek war, societies seek peace. Their contribution shows that the positions held by interviewees in Ukraine and Russia on the Minsk Process and the key issue of how and whether to restore Ukrainian statehood in non-governmen- 
tal controlled areas are largely identical to the official positions of the warring sides.

Of course, there is also hope among the bleakness. The OSCE has always been a club of non-likeminded states; labelling 2020 as the worst year in the organization's history glosses over the many stormy periods the OSCE has weathered since the 1990 Charter of Paris. In fact, the OSCE has shown resilience as an organization in 2020, and its commitments, though often violated, remain essential to regulating conduct within and between states. All of the authors in this volume highlight opportunities for more sustainable and equitable OSCE activities.

Regarding Central Asia, I argue that OSCE activities can bring concrete benefits to local populations even if they do not change domestic distributions of power. Baker's and Raith's reports identify further political support and resources as key conditions for improving compliance with OSCE commitments (Baker) and the OSCE's ability to manage conflict (Raith). Evers et al. make practical recommendations for closer inter-organizational relations, including by creating space for informal interaction between senior representatives of the OSCE and the Council of Europe. On Karabakh, Remler et al. argue that the Minsk Group could help to set up CSBMs, support negotiations on the future status of the disputed territory, and work towards a regional peace agreement. Schaller recommends that future CSBMs should pay more attention to multilateral verification and confidence-building (among other measures) on the political-strategic level. Applying negotiation theory, Druey et al. move from comparing divergent positions to identifying underlying interests. The latter reveal commonalities that leave room for reaching a durable and peaceful solution to the violence in the Donbas.

Indeed, the 2020 Ministerial Council demonstrated that OSCE participating States have an interest in keeping the OSCE alive. Governments adopted decisions on issues on which there is relative consensus, such as the fight against organized crime, and even affirmed the continuing relevance of human rights norms and commitments, passing a decision on the prevention and eradication of torture. Most importantly, they filled the four top positions of the Secretariat and the institutions. At the same time, however, interpretative statements, especially those of the United States and Russia, indicate that powerful participating States hold very different views on the authority and policy priorities of the OSCE apparatus.

I am grateful to the many friends and colleagues who made it possible to produce OSCE Insights under the difficult conditions of 2020. The authors invested much time in writing the texts and revising them, sometimes enduring several rounds of revision. External reviewers responded quickly to our invitations to comment on texts and adapted their evaluation criteria to the expectations of our readers. Many thanks also go to the OSCE Insights team: Carolyn Benson, Ursula Froese, Alona Shestopalova, Caroline Taylor, and our translators and editors for the Russian and German language editions. The team also received support from other IFSH colleagues, es- 
pecially Frank Evers, Britta Fisch, Alexandra Harm, Sonja Objartel, and Barbara Renne. Eva Lang and Martin Reichinger of Nomos never complained when we made adjustments to the proofs and accommodated our desire to see the papers online as soon as possible. The German Federal Foreign Office provided generous funding, as well as ideas and contacts. Special thanks go to Ursel Schlichting, who retired from the IFSH at the end of 2020. For over twenty years, she ensured that the OSCE Yearbook was a vital forum for OSCE debate. OSCE Insights will continue to build on this firm foundation. 
